\title{
Retinoid receptor-specific agonists regulate bovine in vitro early embryonic development, differentiation and expression of genes related to cell cycle arrest and apoptosis
}

\author{
A. Rodríguez ${ }^{\text {a }}$, C. Díez ${ }^{\text {a }}$, J.N. Caamaño ${ }^{\text {a }}$, C. de Frutos ${ }^{\text {a }, ~ L . J . ~ R o y o ~}{ }^{\text {a }}$, \\ M. Muñoz ${ }^{\mathrm{a}}$, S. Ikeda ${ }^{\mathrm{b}}$, N. Facal ${ }^{\mathrm{a}}$, M. Álvarez-Viejo ${ }^{\mathrm{c}}$, E. Gómez $^{\mathrm{a}, *}$ \\ ${ }^{a}$ Genética y Reproducción SERIDA, Asturias, Spain \\ ${ }^{\mathrm{b}}$ Livestock Farm of the Graduate School of Agriculture, Kyoto University, Kyoto Prefecture, Japan \\ ${ }^{\mathrm{c}}$ Hospital Universitario Central de Asturias, Laboratorio de Trasplantes y Terapia Celular, Asturias, Spain
}

Received 7 June 2007; received in revised form 27 July 2007; accepted 3 August 2007

\begin{abstract}
A major goal in reproductive biotechnology is the identification of pathways that regulate early embryonic development and the allocation of cells to the inner cell mass (ICM) and trophectoderm (TE). Retinoids regulate the development and differentiation of the bovine blastocyst in vitro, although the involvement of the retinoid X receptors (RXRs) remains to be clarified. This paper compares the effect of a synthetic RXR agonist (LG100268; LG) with that of the retinoic acid receptor (RAR) agonist all-trans retinoic acid (ATRA) on blastulation. In vitro-produced morulae were treated for $48 \mathrm{~h}$ with $\mathrm{LG}(0.1 \mu \mathrm{M}, 1 \mu \mathrm{M}$ and $10 \mu \mathrm{M})$, ATRA $0.7 \mu \mathrm{M}$, or no additives. Treatment with ATRA did not increase the rate of development; however, the LG $0.1 \mu \mathrm{M}$ treatment increased both the blastocyst development and hatching rate. Cell numbers increased in the ICM with LG $10 \mu \mathrm{M}$, while a dosedependent reduction was observed in the TE in the presence of LG. Gene expression levels of p53 and p66 did not vary with LG but increased with ATRA. Both LG and ATRA activated bax, a pro-apoptotic gene and H2A.Z, a cell cycle-related gene. The above effects suggest the existence of active p53-dependent and -independent apoptotic pathways for ATRA and LG, respectively, in the bovine embryo. The expression of $\mathrm{p} 53$ and H2A.Z showed a strong, positive correlation $(r=0.93 ; p<0.0001)$ in all experimental groups; both proteins are linked through the cell cycle. Agonists of RXR could be used to control blastocyst development and differentiation.
\end{abstract}

(C) 2007 Elsevier Inc. All rights reserved.

Keywords: Bovine embryo; Retinoids; Gene expression; Cell cycle; Differentiation

\section{Introduction}

Vitamin A and its active metabolite retinoic acid (RA) are required for normal embryonic growth and development. The disruption of retinoid homeostasis by exogenous all-trans-RA (ATRA), or the deprivation of

\footnotetext{
* Corresponding author. Tel.: +34 985195300/01; fax: +34985195310 .

E-mail address: egomez@serida.org (E. Gómez).
}

RA, has been associated with abnormalities during late development, a consequence of the alteration of the relationship between cellular retinoid levels and the genetic developmental program [1,2]. In mammalian embryos, many RA-controlled genes are represented by a number of transcription factors, signalling molecules and enzymes, each of which can activate a number of different development-related pathways [3]. The conversion of ATRA to 9-cis-RA and others isomers produces biologically active compounds that enter the nucleus and bind to specific receptors, i.e., retinoic acid 
receptors (RARs) and retinoic X receptors (RXRs) [4], each of which have $\alpha, \beta$ and $\gamma$ subtypes. The RARs are activated by ATRA and 9-cis-RA, whereas the RXRs are activated only by 9-cis-RA. The non-specific binding of 9-cis-RA to both retinoid receptors hinders the study of RXR transactivation. Heterodimerization between RXR and RAR and other members of the steroid/thyroid hormone nuclear receptor superfamily may occur in response to ligand-mediated activation [4]. Heterodimers bind to specific DNA sequences, known as RA-responsive elements, which consist of two direct repeat half-sites with the consensus sequence AGGTCA. According to the literature, transactivation often increases the expression of genes that are normally silent in the absence of their ligands. Transcripts of all retinoid subtypes of RXR and RAR (except for RAR $\beta$ ) are expressed during the preimplantation stages in bovine embryos produced in vitro [5-7]. Immunostaining techniques have detected $\operatorname{RAR} \alpha, \operatorname{RAR} \gamma-2$ and RXR $\beta$ in blastocysts [5,6] and RAR $\alpha$ and RXR $\beta$ in cumulus cells [8].

In cattle, knowledge of the role of retinoids during early embryonic development in vitro is limited. We have shown that $\mathrm{ROH}$ stored in the bovine morula can be made functionally active by conversion to RA during blastocyst formation [9]. Morulae treated for $24 \mathrm{~h}$ with ATRA give rise to blastocysts with increased cell proliferation in the TE and ICM, a lower necrotic index, and an unaffected apoptotic index, although the ICM/ TE apoptotic frequency ratio is directly dependent on retinoid activity [9]. The present work examines the involvement of the RAR and RXR pathways in bovine embryonic development via the use of the RAR agonist ATRA and a synthetic specific RXR agonist (LG100268; LG, a gift of Ligand Laboratories). Blastocyst development and differentiation were analysed, as was the expression of p53, p66 and bax (genes involved in growth, arrest and apoptosis) and histone H2A.Z (a histone H2A variant essential to nucleosome stability during embryonic development) [10].

\section{Materials and methods}

\subsection{In vitro embryo production}

Bovine cumulus-oocyte complexes (COCs) were aspirated from $3 \mathrm{~mm}$ to $8 \mathrm{~mm}$ follicles collected from ovaries removed at the slaughterhouse. Those COCs with a compact cumulus and homogeneous ooplasm were rinsed three times with HEPES-buffered TCM199 (Invitrogen, Barcelona, Spain) containing $0.4 \mathrm{mg} / \mathrm{mL}$ bovine serum albumin (BSA) (Sigma, Madrid, Spain), and twice with maturation medium (TCM199, 10\% foetal calf serum (FCS), $1 \mu \mathrm{g} / \mathrm{mL}$ of porcine $\mathrm{FSH}$ (F2293 Sigma), $5 \mu \mathrm{g} / \mathrm{mL}$ of sheep LH (L5269 Sigma) and $1 \mu \mathrm{g} / \mathrm{mL}$ of $17 \beta$-estradiol (E8875 Sigma)). Groups of 40-50 oocytes were allowed to mature in vitro in four-well culture dishes (Nunc; Barcelona, Spain) for $24 \mathrm{~h}$ at $39{ }^{\circ} \mathrm{C}$ and with $5 \% \mathrm{CO}_{2}$ in humidified air. Matured oocytes were co-cultured for $18-20 \mathrm{~h}$ with swim-up separated sperm (Day 0) as described by Hidalgo et al. [11]. The remaining cumulus cells were detached using a vortex and the zygotes cultured in droplets of B2 medium (INRA-Menezo, Paris, France) with Vero cell monolayers at $39{ }^{\circ} \mathrm{C}$, with $5 \% \mathrm{CO}_{2}$ in humidified air and under mineral oil, until $139 \mathrm{~h}$ after insemination (Day 6). Day 6 morulae and early blastocysts (with not more than $8 \%$ showing incipient cavitation) were equally distributed among the experimental groups. All groups were cultured from Day 6 to Day 8 (at $39{ }^{\circ} \mathrm{C}$ with $5 \% \mathrm{CO}_{2}$ and $90 \% \mathrm{~N}_{2}$ in humidified air) in four-well dishes (Nunc) containing $400 \mu \mathrm{l}$ of modified synthetic oviduct fluid (mSOF; containing amino acids, citrate, myo-inositol and 5\% FCS), supplemented with one of the following: LG $0.1 \mu \mathrm{M}$, LG $1 \mu \mathrm{M}, \mathrm{LG} 10 \mu \mathrm{M}$ and ATRA $0.7 \mu \mathrm{M}$ [9] and no additives. Both LG and ATRA were dissolved in dimethylsulphoxide (DMSO). The concentration of the vehicle in the culture was adjusted to $0.1 \%$ in all groups. Embryonic development was recorded as being at the early (blastocoele occupying less than half of the embryonic mass), mid (blastocoele occupying more than half of the embryonic mass), expanded (blastocoele expansion leaving no free space inside the zona pellucida, which appears thinner and enlarged in diameter) or hatched blastocyst stage (zona pellucida is broken down and the embryo protrudes or is fully outside of the zona). On Day 8, the diameter of the expanded embryos was measured, and hatched embryos were subjected to differential cell counts and gene expression analysis.

\subsection{Differential cell counts}

Blastocysts were fixed and stained for differential cell counting as described by Thouas et al. [12]. All were incubated in $500 \mu$ l of BSA-free TCM199 HEPES (Invitrogen) with $1 \%$ Triton-X-100 and $100 \mu \mathrm{g} / \mathrm{mL}$ propidium iodide for $30 \mathrm{~s}$. They were then fixed in $500 \mu \mathrm{L}$ of ethanol with $25 \mu \mathrm{g} / \mathrm{mL}$ of bisbenzimide (Hoechst 33342) and stored overnight at $4{ }^{\circ} \mathrm{C}$. Fixed and stained blastocysts were transferred directly into a glycerol microdrop on a glass microscope slide. Cell counts were made using digital images obtained with an 
inverted microscope equipped with a UV-excitation filter at $330-385 \mathrm{~nm}$ and a barrier filter at $420 \mathrm{~nm}$. TE cells were identified by their red fluorescence; the ICM cells were blue.

\subsection{RNA extraction}

Pools of four to six hatched blastocysts were stored in RNA-Later (Ambion, Austin, TX, USA), kept overnight at $4{ }^{\circ} \mathrm{C}$, and then stored at $-80{ }^{\circ} \mathrm{C}$. Isolation of mRNA was performed using the Dynabeads mRNA Direct KIT (Dynal, Oslo, Norway) following the manufacturer's instructions. Samples were added to $180 \mu \mathrm{l}$ of Dynabeads oligo (dT)25 (Dynal) and allowed to anneal for 10 min. Poly(A) RNA-bead complexes were separated from the binding buffer and rinsed in buffers $\mathrm{A}$ and $\mathrm{B}$ (Dynal) using a magnetic separator. Poly(A) RNA was finally eluted in $180 \mu \mathrm{l}$ of $10 \mathrm{mM}$ Tris-HCl.

\subsection{Reverse transcription}

RNA reverse transcription was performed for each experimental group from hatched blastocysts using the first-strand complementary DNA (cDNA) synthesis kit for RT-PCR, (AMV; Roche, Barcelona, Spain) with oligo $\mathrm{d}(\mathrm{T})$ and random primers, following the manufacturer's instructions. The tubes were then incubated at $25{ }^{\circ} \mathrm{C}$ for 10 min to allow annealing. The RNA was subsequently reverse-transcribed at $42{ }^{\circ} \mathrm{C}$ for $60 \mathrm{~min}$, followed by 5 min incubation at $99{ }^{\circ} \mathrm{C}$ to denature the enzyme. The oligo $\mathrm{d}(\mathrm{T})$ and random primer samples were then cooled at $4{ }^{\circ} \mathrm{C}$ and stored at $-20{ }^{\circ} \mathrm{C}$ until use.

\subsection{Gene expression}

Expression analysis included the genes p53, p66, bax and histone H2A.Z. The candidate reference genes analysed were beta actin (actin), tyrosine 3-monooxygenase/tryptophan 5-monooxygenase activation protein, zeta polypeptide (YWHAZ), laminin B, glyceraldehyde-3-phosphate dehydrogenase (GAPDH), ubiquitin and hypoxanthine phosphoribosyl-transferase (HPRT).

Quantitative PCR was performed with an i-Cycler iQ Real-Time PCR Detection System (Bio-Rad, Hercules, CA, USA). SYBR Green PCR Supermix $(2 \times)$ (BioRad) was used as a double-stranded DNA-specific fluorescent dye. Assays were performed in triplicate. The reaction mixture for amplification consisted of $2 \mu \mathrm{l}$ of cDNA in a final reaction volume of $20 \mu$ l. Table 1 shows the primer details. The RT-PCR protocol included an initial step of $95{ }^{\circ} \mathrm{C}(3 \mathrm{~min})$, followed by

Table 1

Details of primers used for quantitative real-time PCR on bovine hatched blastocysts

\begin{tabular}{|c|c|c|c|c|c|}
\hline Gene & Primer sequence (concentration, $\mu \mathrm{M}$ ) & $\begin{array}{l}\text { Fragment } \\
\text { size (bp) }\end{array}$ & $\begin{array}{l}\text { Annealing } \\
\text { temperature }\left({ }^{\circ} \mathrm{C}\right)\end{array}$ & $\begin{array}{l}\text { Accesion } \\
\text { number }\end{array}$ & Reference \\
\hline p53 & $\begin{array}{l}\text { CTCAGTCCTCTGCCATACTA }(0.2) \\
\text { GGATCCAGGATAAGGTGAGC }(0.2)\end{array}$ & 364 & 56.4 & U74486 & [37] \\
\hline p66 & $\begin{array}{l}\text { GGTTCGGACAAAGGATCACC }(0.2) \\
\text { GTGAGGTCTGGGGAGAAGC }(0.2)\end{array}$ & 334 & 58 & BC122688 & [37] \\
\hline Bax & $\begin{array}{l}\text { TGAGCGAGTGTCTGAAGC }(0.1) \\
\text { GCCTTGAGCACCAGTTTG }(0.1)\end{array}$ & 196 & 60 & U92569 & Authors' design \\
\hline H2A.Z & $\begin{array}{l}\text { AGGACGACTAGCCATGGACGTGTG }(0.2) \\
\text { CCACCACCAGCAATTGTAGCCTTG }(0.2)\end{array}$ & 208 & 60 & NM_174809 & [47] \\
\hline Actin & $\begin{array}{l}\text { CGGATGTCCACGTCACACTTC }(0.2) \\
\text { GACTACCTCATGAAGATCCTC }(0.2)\end{array}$ & 299 & 60 & E00829 & Authors' design \\
\hline YWHA & $\begin{array}{l}\text { ACCAGTCACAGCAAGCATACC }(0.2) \\
\text { GTATCCGATGTCCACAATGTCAAG }(0.2)\end{array}$ & 268 & 60 & NM_174814 & Authors' design \\
\hline Lamin B & $\begin{array}{l}\text { ACTGACCTCATCTGGAAGAACC }(0.1) \\
\text { CAAAACTTTCAGTGTCAAAAAGG }(0.1)\end{array}$ & 384 & 60 & XM_003777 & {$[22]$} \\
\hline Ubiquitin & $\begin{array}{l}\text { GGAGCCCAGTGACACCATCG }(0.1) \\
\text { TGCCTTCCTTATCCTGGATCTTGG }(0.1)\end{array}$ & 284 & 60.8 & Z18245 & Authors' design \\
\hline HPRT & $\begin{array}{l}\text { CGAGATGTGATGAAGGAGATGG }(0.2) \\
\text { GCCTGTTGACTGGTCGTTAC }(0.2)\end{array}$ & 186 & 58.2 & AF176419 & Authors' design \\
\hline GAPDH & $\begin{array}{l}\text { GTCACCAGGGCTGCTTTTAATTC }(0.1) \\
\text { CCAGCCTTCTCCATGGTAGTGA }(0.1)\end{array}$ & 274 & 58 & U85042 & Authors' design \\
\hline
\end{tabular}


45 cycles of $30 \mathrm{~s}$ at $95^{\circ} \mathrm{C}$ for DNA denaturation, $40 \mathrm{~s}$ for primers annealing (see Table 1 for each gene temperature) and a primer extension step of $40 \mathrm{~s}$ at $72{ }^{\circ} \mathrm{C}$. Fluorescence data were acquired at $72{ }^{\circ} \mathrm{C}$. Melting-curve analyses to confirm product specificity were performed immediately after amplification following 1 min denaturation at $95{ }^{\circ} \mathrm{C}, 1 \mathrm{~min}$ annealing at $65^{\circ} \mathrm{C}$ and 60 cycles with $0.5^{\circ} \mathrm{C}$ increments ( $10 \mathrm{~s} \mathrm{each}$ ) beginning at $65^{\circ} \mathrm{C}$, while monitoring fluorescence. The melting temperature was always $>80{ }^{\circ} \mathrm{C}$. Product identity was confirmed by electrophoresis in $2 \%$ agarose gels in $1 \times$ TBE buffer and staining with ethidium bromide. The standard curve was produced using cDNA prepared as above and serially diluted. The amplification efficiency and correlation coefficients were higher than $80 \%$ and 0.98 , respectively.

The target gene $\mathrm{Ct}$ (cycle threshold) values were transformed using the comparative delta-delta- $\mathrm{Ct}(\Delta \Delta \mathrm{Ct})$ method. This transforms $\mathrm{Ct}$ values into normalized relative expression values, according to a reference $\mathrm{Ct}$ value and a normalization factor (NF). The NF was obtained using the geNorm applet as described by Vandesompele et al. [13]. Briefly, the gene expression stability measure $(M)$ for a reference candidate gene was calculated as the average pairwise variation $(V)$ for that gene together with five other reference genes. Stepwise exclusion of the gene with the highest $M$ value ranked the reference genes according to their expression stability. To determine how many reference genes should be used, NFs were calculated by stepwise inclusion of an extra, less stable reference gene according to Vandesompele et al. [13]. The final NF corresponded to the geometric mean of the most stable reference genes.

\subsection{Statistical analysis}

Development rates were analysed in two steps. First, the factors significantly influencing data were identified by categorical data modelling (CATMOD) using SAS Version 8.2 software (1999; SAS/STAT ${ }^{\circledR}$ Institute Inc., Cary). CATMOD fits linear models to response frequency functions. Treatments and replicates were found to have significant influence on the dependent variables. Secondly, those factors identified as significant were used to produce a linear model using the general linear models procedure (GLM; SAS software). Blastocyst cell counts and gene expression analysis were also performed using the SAS GLM procedure to fit linear models (the treatments and replicates were used as fixed effects). The GLM procedure performs analysis of variance for unbalanced data and was used to estimate the least square means (LSM) for each fixed effect with a significant $F$ value. Duncan's multiplerange test was used to compare the raw means calculated for the main effects. Development data were transformed to frequency percentages, blastocyst cell counts and diameters were handled as absolute values, and gene expression was represented by arbitrary units. Correlations among the expression levels of the analysed genes were calculated for the whole dataset and for each treatment using the Proc CORR routine (SAS/STAT software).

\section{Results}

\subsection{Blastocyst development}

A total of 1513 morulae and early blastocyst (over 15 replicates) $-33.5 \%$ of the cultured oocytes - were selected for the experimental procedure. Table 2 shows the blastocyst development data and total embryos within each experimental group. Embryos cultured in the presence of LG $0.1 \mu \mathrm{M}$ showed improved blastocyst development rates on Day 7 and hatching rates on Day 8 , and had larger diameters. Differences between the LG $0.1 \mu \mathrm{M}$ and the controls tended to be significant on

Table 2

Blastocyst development rates: percentages of Day 6 bovine morulae that developed to blastocyst at the indicated stages after a $48 \mathrm{~h}$ culture period in mSOF containing $0.7 \mu \mathrm{M}$ RAR agonist all-trans retinoic acid (ATRA), no additives (control group) or $0.1 \mu \mathrm{M}, 1 \mu \mathrm{M}, 10 \mu \mathrm{M}$ of a RXR agonist LG100268 (LG)

\begin{tabular}{|c|c|c|c|c|c|c|c|c|}
\hline \multirow[t]{2}{*}{ Treatment } & \multirow[t]{2}{*}{$N$} & \multicolumn{3}{|c|}{ Day 7 blastocysts (\%) } & \multicolumn{4}{|c|}{ Day 8 blastocysts (\%) } \\
\hline & & Early & Medium & Expanded & Medium & Expanded & Hatched & Diameter* \\
\hline ATRA $0.7 \mu \mathrm{M}$ & 298 & $56.1 \pm 2.2$ & $35.5 \pm 2.1$ & $12.1 \pm 1.9 \mathrm{~b}$ & $59.1 \pm 2.6$ & $40.7 \pm 2.5$ & $12.0 \pm 2.2 \mathrm{~b}$ & $181.3 \pm 3.4 \mathrm{c}$ \\
\hline No additives & 295 & $53.7 \pm 2.1$ & $33.4 \pm 2.0 \mathrm{~b}$ & $16.5 \pm 1.8$ & $53.2 \pm 2.5$ & $39.3 \pm 2.4$ & $13.9 \pm 2.1$ & $183.8 \pm 3.9 \mathrm{bc}$ \\
\hline LG $0.1 \mu \mathrm{M}$ & 299 & $58.1 \pm 2.1$ & $40.7 \pm 2.0 \mathrm{a}$ & $19.1 \pm 1.8 \mathrm{a}$ & $59.3 \pm 2.5$ & $45.9 \pm 2.4$ & $19.0 \pm 2.1 \mathrm{a}$ & $198.2 \pm 3.7 \mathrm{a}$ \\
\hline LG $1 \mu \mathrm{M}$ & 298 & $58.6 \pm 2.2$ & $40.1 \pm 2.1 \mathrm{a}$ & $16.7 \pm 1.9$ & $60.3 \pm 2.6$ & $43.5 \pm 2.5$ & $13.3 \pm 2.2$ & $188.8 \pm 3.6$ \\
\hline LG $10 \mu \mathrm{M}$ & 323 & $53.2 \pm 2.1$ & $34.4 \pm 2.0 \mathrm{~b}$ & $15.8 \pm 1.8$ & $57.8 \pm 2.5$ & $41.6 \pm 2.4$ & $12.2 \pm 2.1 \mathrm{~b}$ & $189.9 \pm 3.5 \mathrm{ab}$ \\
\hline
\end{tabular}

$N=$ Day 6 morulae; data are LSM \pm S.E.M. percentages from cultured morulae (15 replicates); different letters (a, b, c) in the same column express significant differences: $p<0.05$. $(*) \mu \mathrm{m}$ in expanded blastocysts. 

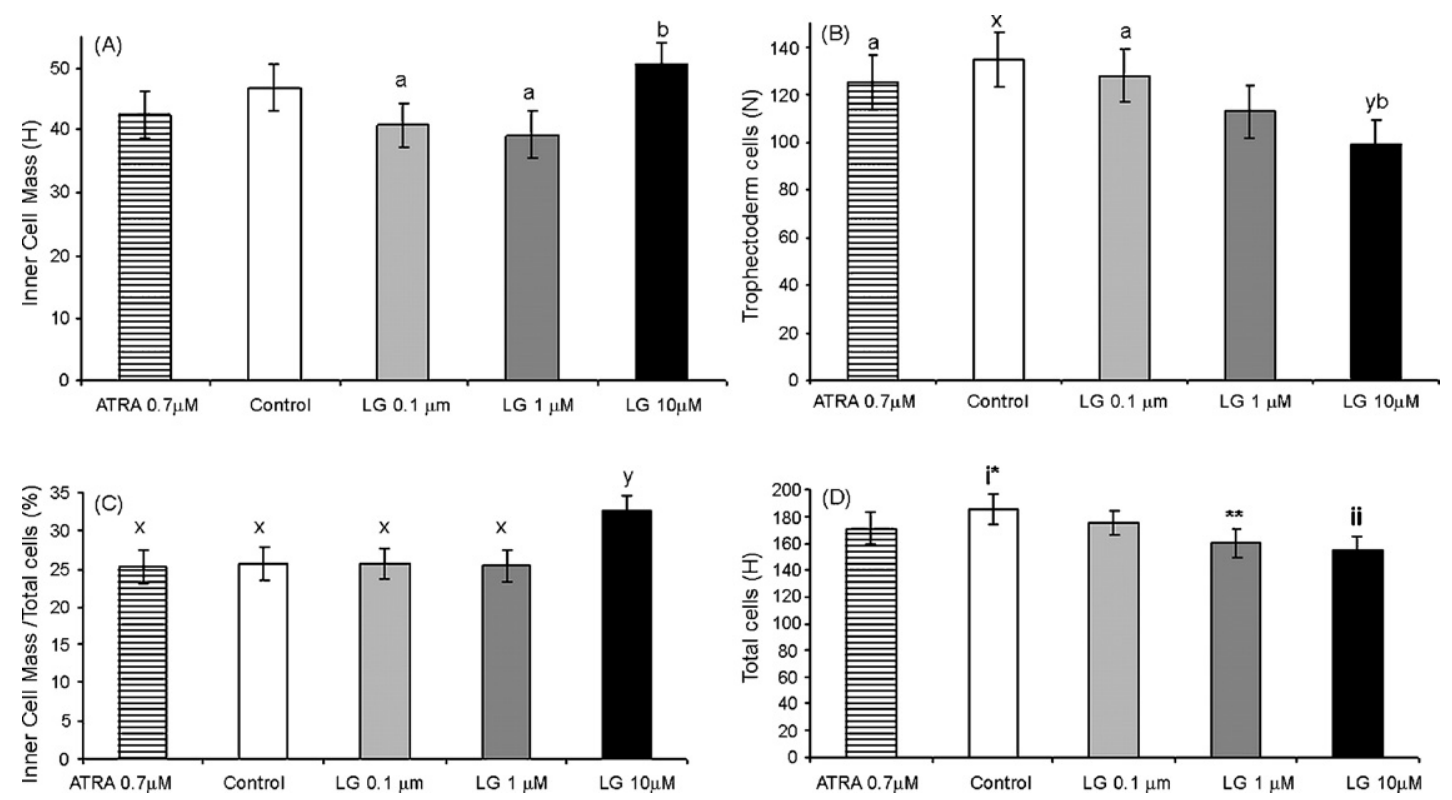

Fig. 1. Cell counts of Day 8 hatched blastocysts derived from Day 6 morulae after a $48 \mathrm{~h}$ culture period in mSOF containing $0.7 \mu \mathrm{M}$ RAR agonist all-trans retinoic acid (ATRA), no additives (control group) or $0.1 \mu \mathrm{M}, 1 \mu \mathrm{M}, 10 \mu \mathrm{M}$ of the RXR agonist LG100268 (LG): (A) number of cells within the inner cell mass, (B) number of cells within the trophectoderm, (C) percentage of ICM/total cells and (D) total cells. Different letters express significant differences-x, y $(p<0.02)$; a, b $(p<0.06)$; i, ii $(p=0.03)$; *** $(P<0.10)$.

Day 8 at the expanded and hatched stage $(p<0.10$; not shown in table). At a concentration of $1 \mu \mathrm{M}, \mathrm{LG}$ only had an effect on Day 7 medium blastocyst rates; the LG $10 \mu \mathrm{M}$ treatment had no effect. Blastocyst development in ATRA-containing medium did not differ from that recorded when no additives were present, although development traits contrary to that seen in embryos cultured with LG $0.1 \mu \mathrm{M}$ were observed.
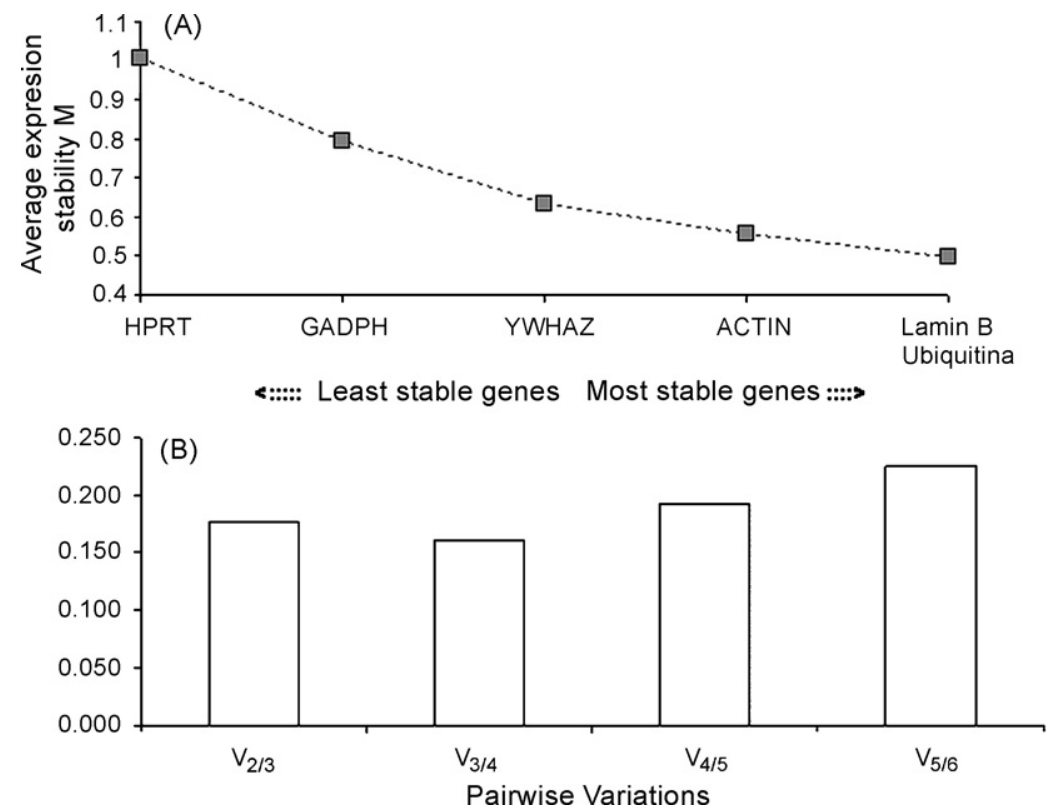

Fig. 2. Gene expression stability of the candidate reference genes analyzed by the geNorm program. (A) Average expression stability values $(M)$ of the control genes, showed from least stable (left) to most stable (right). (B) Pairwise variation analysis: determination of the optimal number of control genes for normalization. 

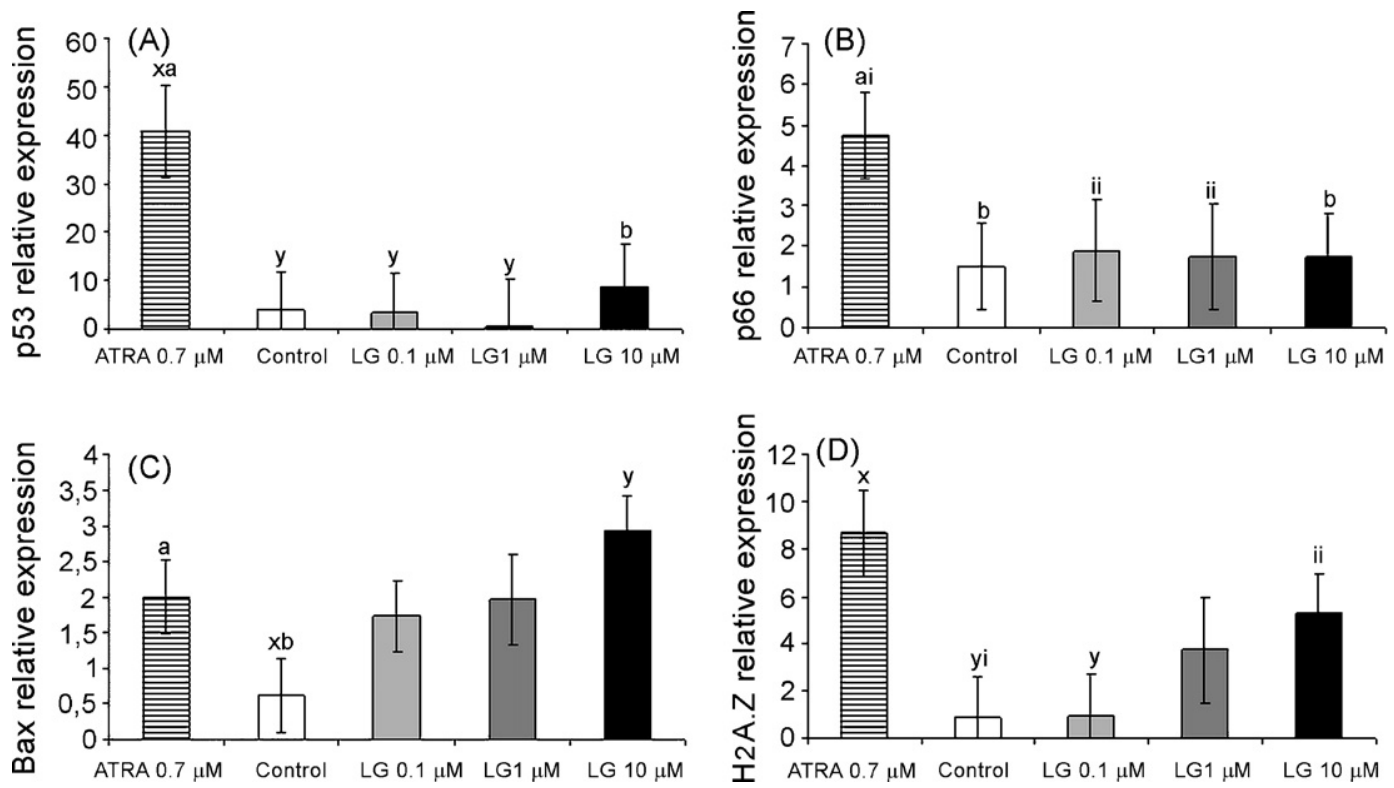

Fig. 3. Quantitative gene expression (arbitrary units) in Day 8 hatched blastocysts derived from Day 6 morulae after a $48 \mathrm{~h}$ culture period in mSOF containing $0.7 \mu \mathrm{M}$ RAR agonist all-trans retinoic acid (ATRA) or no additives (control group) or $0.1 \mu \mathrm{M}, 1 \mu \mathrm{M}, 10 \mu \mathrm{M}$ of a RXR agonist LG100268 (LG): (A) p53 relative expression, (B) p66 relative expression, (C) Bax relative expression and (D) histone H2A.Z relative expression. Different letters express significant differences-x, y $(p<0.01)$; $\mathrm{a}, \mathrm{b}(p<0.05)$; i, ii $(P<0.10)$.

\subsection{Differential cell counts}

Fig. 1 shows the differential cell counts. The presence of LG $10 \mu \mathrm{M}$ increased the number of cells allocated to the ICM and the ICM/total cells percentage. However, the number of cells in the TE was reduced by LG in a dose-dependent manner; the TE proliferative pattern was reflected in the total number of cells counted.

\subsection{Gene expression}

Gene expression was analyzed in eight replicates. The most stable housekeeping gene was selected from a set of six candidates (see Table 1). Laminin B, ubiquitin and beta actin were the three more stable genes; HPRT was found to be the least stable (Fig. 2A). Fig. 2B shows the pairwise variation $(\mathrm{V} n / \mathrm{V} n+1)$ between two sequential NFs: NF $n$ and NF $n+1$. A large variation means that the added gene have a significant effect and should probably be included in the calculation of the final NF. In this case, the inclusion of a fourth gene had no significant effect ( $V_{2 / 3}$ of 0.177 compared to $V_{3 / 4}$ of $0.160)$ on the NF. The higher $V_{5 / 6}(0.225)$ and $V_{6 / 7}$ (0.210) values are due to the inclusion of a relatively unstable gene and are in line with the average expression stability $M$. Therefore, the final NF was calculated based on the geometric mean of the gene expression values for laminin $\mathrm{B}$, ubiquitin, actin and
YWHAZ (the most stable genes). Fig. 2A shows the ranking of the six control genes according to their $M$ values.

As shown in Fig. 3, the expression of both p53 and p66 genes was dependent on ATRA and independent of LG. However, the bax gene was stimulated by ATRA and, in a dose-dependent manner, by LG. The treatment of embryos with ATRA triggered H2A.Z gene expression, while the presence of LG had no effect at concentrations of $0.1 \mu \mathrm{M}$ and $1 \mu \mathrm{M}$; a trend towards differing from the controls $(p<0.10)$ was recorded in the presence of $10 \mu \mathrm{M}$ LG. The greatest variation in gene expression was shown by H2A.Z and p53, which showed a very strong and significant positive correlation $(r=0.93 ; p<0.0001)$. Indeed, H2A.Z and p53 correlated strongly in all experimental groups (values between $0.76(p<0.005)$ for controls and 0.98 $(p<0.0001)$ in embryos treated with ATRA). p66 and bax expressions were positively correlated $(R=0.57 ; p<0.0003)$ in embryos treated with LG $10 \mu \mathrm{M}$. The expression of p53 and bax correlated in the ATRA and control groups; no such association was observed with any LG concentration (data not shown).

\section{Discussion}

The present work shows that LG100268 (48 h treatment), a RXR specific ligand, affects both the 
blastocyst rate and differentiation in a dose-dependent manner.

Only the treatment with $0.1 \mu \mathrm{M}$ LG for $48 \mathrm{~h}$ improved the blastocyst and hatching rates. Culturing for $48 \mathrm{~h}$ with ATRA did not improve the blastocyst development and hatching rates, nor did it affect the ICM and TE cell counts. These results contrast with those reported in our previous work, where a shorter exposure to ATRA $(24 \mathrm{~h})$ increased the hatching rate and triggered strong cell proliferation in the ICM and the TE [9]. If overexposure to retinoids can be defined on the basis of dose or time (or both), $48 \mathrm{~h}$ of culture in the presence of ATRA might be considered excessive (whereas $24 \mathrm{~h}$ is not). We previously reported that overexposure ( $48 \mathrm{~h}$ ) of cattle oocytes to 9-cis-RA prior to fertilization reduced blastocyst rates, in contrast to oocytes incubated for $24 \mathrm{~h}$ with 9-cis RA either during meiotic inhibition or in vitro maturation $[11,14,15]$. The detrimental effects of high dosage were reported by Huang et al. [16] in mice embryos exposed for $24 \mathrm{~h}$ to $10 \mu \mathrm{M}$ ATRA. These authors found antiproliferative and pro-apoptotic effects that mainly targeted the ICM [17]. Concentrations of ATRA between $0.3 \mu \mathrm{M}$ and $1 \mu \mathrm{M}$ are commonly encountered in the literature on reproductive cells $[9,18,19]$. Finally, a concentration of $1 \mu \mathrm{M}$ ATRA during IVM can improve blastocyst development (Ikeda $S$, personal communication).

To date, most standardizations against internal control genes have involved actin, glyceraldehyde-3phosphate dehydrogenase (GAPDH) or $18 \mathrm{~S}$ rRNA reference genes. However a number of studies have provided solid evidence that their transcription levels are not constant throughout development and differ between experimental conditions [20-22]. Consequently, a previous validation of candidate reference genes is crucial for an accurate analysis of gene expression, since the use of a single, conventional gene for normalization can lead to errors [13,23]. The authors of this report suggest to pay special attention to selecting reference genes belonging to different functional classes, which significantly reduces the chance of co-regulation. In our work, the expression levels of laminin B, ubiquitin, actin and YWHAZ genes were found to be the most stable, while HPRT was the least stable (Fig. 2A).

Together with nucleosomes, histones participate directly in the regulation of gene expression. Certainly, they affect the transcription of genes required for normal progression through the cell cycle. Chromatinmodifying enzymes mark histone residues and change nucleosome conformation, allowing the transcriptional machinery to transcribe or repress genes [24]. This occurs through the action of a DNA deposition signal and a specific pattern of histone tail acetylation [25]. In Drosophila melanogaster, H2A.Z localizes to the promoter of genes that have been inactivated, but is subsequently lost from these upon induction [26]. Interestingly, the H2A.Z sequence is conserved across many species [27]. In the present work, the presence of ATRA clearly increased the expression of H2A.Z. The existence of an RXR control of H2A.Z expression needs to be further researched: the pattern seen in the present work was unclear. In eukaryotic cells, chromosome replication requires the synthesis of histones to package newly replicated DNA into chromatin. The control of the histone mRNA level accounts for much of the control of histone protein synthesis [28]. However, it is still an open question as to how the expression of individual histone genes is controlled. Interestingly, the present work showed a strong linkage between H2A.Z and p53 gene expression in all five experimental groups; it is therefore independent of experimental conditions. This might indicate the existence of an important constitutive mechanism. It is intriguing how H2A.Z synthesis, which persists throughout the cell cycle at a steady level [29], should vary depending on p53. In fact, despite that seen in the mouse, the histone H2A.Z is regulated in a replication-independent manner and its expression level is higher than those of the other $\mathrm{H} 2 \mathrm{a}$ genes. A relationship between the maintenance of genomic integrity and H2A.Z has recently been suggested [30]. However, to our knowledge there is no evidence of a relationship between p53 and H2A.Z, such as we found in the present work. The cell cycle arrest is a primary effect induced by $\mathrm{p} 53$ for DNA repair upon genotoxic stress. The protein $\mathrm{p} 53$ is involved in the transition from the $\mathrm{G} 1$ to the $\mathrm{S}$ phase checkpoints, and at the $S$ phase and G2/M checkpoints [31]. The onset of p53 transcription occurs before DNA synthesis, and p53 production peaks during the transition from the G1 to $S$ phase [32]. As H2A.Z production begins to decrease at the end of the $S$ phase [33] in coincidence with one of the p53 checkpoints, the expression pattern of both genes could be related through the cell cycle.

The presence of ATRA for $24 \mathrm{~h}$ [9] and $48 \mathrm{~h}$ (this work) increases p53 gene expression in hatched blastocysts. However, a $24 \mathrm{~h}$ exposure does not reduce the development rate [9], unlike that which occurs with a $48 \mathrm{~h}$ overexposure. A similar reduction in development rates, in coincidence with a strong up-regulation and nuclear accumulation of $\mathrm{p} 53$, has been reported in mouse blastocysts cultured in vitro, but not in their in vivo counterparts [34]. In addition, bax expression correlated with p53 expression in ATRA and untreated 
controls, while this association was not observed under LG stimulation; this is consistent with the detected responsiveness of p53 to ATRA but not to LG. All the relevant correlations detected in the present work were positive, although p53 downstream effects were different depending on the retinoid receptor affected. When the RAR pathway was stimulated by ATRA, the effect of p53 appeared to be linked to the pro-apoptotic factor bax. This correlation was even observed in nonstimulated embryos, probably because of their endogenous RA activity [9]. This correlation was not seen in any $\mathrm{LG}$ treatment.

The protein p66 has been associated with cellular oxidative stress [35,36], embryonic arrest [37], proliferation [38], apoptosis [39] and cellular senescence [36]. In bovine embryos produced in vitro, p66 mRNA expression gradually decreases from the zygote to the blastocyst stage [37]. Protein p66 is downstream to p53 in a p53-dependent apoptosis mechanism [40]. In contrast to embryos that suffer developmental arrest, morulae and blastocysts with full developmental capability show low p66 levels [37]. Thereby, the high p66 expression levels seen in the embryos treated with ATRA for $48 \mathrm{~h}$ are consistent with their reduced diameters and ability to hatch in comparison with those treated with LG $0.1 \mu \mathrm{M}$. In human cell lines with a nonfunctional p53 gene (because it is either absent or has been inactivated), p66 plays a pro-apoptotic role [41]. The present work shows that $\mathrm{p} 66$ and bax expression are highly correlated, although in contrast to bax, p66 is not responsive to LG. Some cancer cell lines treated with 9cis RA, which binds both to RXR and RAR, show G1 arrest, increased bax protein expression, and unaltered p53 levels [42]. A possible explanation of the detrimental effects of retinoid overexposure could be increased apoptosis, as both $48 \mathrm{~h}$ ATRA and $10 \mu \mathrm{M} \mathrm{LG}$ activated pro-apoptotic bax gene. In our work apoptosis markers were determined instead of apoptotic rate, and a direct control for unspecific overall toxic effects of LG treatments lacks. However, because its highly specific binding to RXR, LG100268 has been reported to execute an apoptotic program in rats without undesirable toxicity [43]. On the other hand, RXR agonists binding may lead to heterodimerization with peroxisome proliferator-activated receptors (PPARs), affecting glucose and insulin metabolism [44]. These are effects that could limit the interpretation of our results. In the case of the RAR pathway (i.e., ATRA), upstream activation of p53 and p66 would occur, although neither p53 nor p66 appeared to be associated with the effects of bax through the RXR pathway in the present study. However, consistent with the reduction in cell numbers and the increased expression of bax induced by LG, inhibition of the cell cycle at G1/S phase and apoptosis can be induced through RXR in insulin-producing cells [45]. Thus, apoptosis in the bovine embryo could be mediated both by RXR and RAR, as in many other tissues under different circumstances [46].

In pre-attachment bovine embryos, retinoids have been shown to interact with cell cycle checkpoint components and to be involved in cell proliferation. Although further studies are required to throw light on the links between retinoid pathways, cell proliferation and cell cycle regulation in mammalian embryos, the present study provides some interesting results in this respect. As previously demonstrated in $24 \mathrm{~h}$ ATRA treatments [9], the RXR pathway can also be used to regulate cell proliferation within the TE and the ICM, while LG improves blastocyst hatching and increases embryonic diameters. An apoptosis pathway linked to $\mathrm{RXR}$, which might be independent of p53, is suggested by the present work through the increased bax expression subsequent to LG treatment. In addition, the present results provide strong evidence of linkage between the p53 and H2A.Z genes; both proteins may relate through the cell cycle. Further research is necessary to explore other options for modifying embryonic development and differentiation through the retinoid signalling pathway.

\section{Acknowledgements}

The authors thank Fernando García Ruiz for technical assistance.

Grant support: Spanish Ministry of Education and Science-project AGL2005-04479.

\section{References}

[1] Griffith M, Zile MH. Retinoic acid, midkine and defects of secondary neurulation. Teratology 2000;62:123-33.

[2] Roberts C, Ivins SM, James CT, Scambler PJ. Retinoic acid downregulates Tbx1 expression in vivo and in vitro. Dev Dyn 2005;232:928-38.

[3] McCaffery PM, Dräger UC. Regulation of retinoic acid in the embryonic nervous system: a master differentiation factor. Cytokine Growth Factor Rev 2000;11:233-49.

[4] Chambon P. A decade of molecular biology of retinoic acid receptors. FASEB J 1996;10:940-54.

[5] Mohan M, Malayer JR, Geisert RD, Morgan GL. Expression of retinol-binding protein messenger RNA and retinoic acid receptors in preattachment bovine embryos. Mol Reprod Dev 2001;60:289-96.

[6] Mohan M, Malayer JR, Geisert RD, Morgan GL. Expression patterns of retinoid $\mathrm{X}$ receptors, retinaldehyde dehydrogenase, and peroxisome proliferator activated receptor gamma in bovine preattachment embryos. Biol Reprod 2002;66:692-700. 
[7] Mamo S, Ponsuksili S, Wimmers K, Gilles M, Schellander K. Expression of retinoid $\mathrm{X}$ receptor transcripts and their significance for developmental competence in in vitro-produced preimplantation-stage bovine embryos. Reprod Domest Anim 2005;40:177-83.

[8] Mohan M, Thirumalapura NR, Malayer J. Bovine cumulusgranulosa cells contain biologically active retinoid receptors that can respond to retinoic acid. Reprod Biol Endocrinol 2003; $1: 104$.

[9] Rodríguez A, Díez C, Ikeda S, Royo LJ, Caamaño JN, AlonsoMontes $\mathrm{C}$, et al. Retinoids during the in vitro transition from bovine morula to blastocysts. Hum Reprod 2006;21:2149-57.

[10] Faast R, Thonglairoam V, Schulz TC, Beall J, Wells JR, Taylor $\mathrm{H}$, et al. Histone variant H2A.Z is required for early mammalian development. Curr Biol 2001;11:1183-7.

[11] Hidalgo CO, Díez C, Duque P, Facal N, Gómez E. Pregnancies and improved early embryonic development with bovine oocytes matured in vitro with 9-cis-retinoic acid. Reproduction 2003;125:409-16.

[12] Thouas GA, Korfiatis NA, French AJ, Jones GM, Trounson AO. Simplified technique for differential staining of inner cell mass and trophectoderm cells of mouse and bovine blastocysts. Reprod Biomed Online 2001;3:25-9.

[13] Vandesompele J, De Preter K, Pattyn F, Poppe B, Van Roy N, De Paepe A, et al. Accurate normalization of real-time quantitative RT-PCR data by geometric averaging of multiple internal control genes. Genome Biol 2002;3:34.1-34.11.

[14] Duque P, Díez C, Royo L, Lorenzo PL, Carneiro G, Hidalgo CO, et al. Enhancement of developmental capacity of meiotically inhibited bovine oocytes by retinoic acid. Hum Reprod 2002;17:2706-14.

[15] Gómez E, Royo LJ, Duque P, Carneiro G, Hidalgo C, Goyache F, et al. 9-cis-retinoic acid during in vitro maturation improves development of the bovine oocyte and increases midkine but not IGF-I expression in cumulus-granulosa cells. Mol Reprod Dev 2003;66:247-55

[16] Huang FJ, Shen CC, Chang SY, Wu TC, Hsuuw YD. Retinoic acid decreases the viability of mouse blastocysts in vitro. Hum Reprod 2003;18:130-6.

[17] Huang FJ, Hsu YC, Kang HY, Chang SY, Hsuuw YD, Huang KE. Effects of retinoic acid on the inner cell mass in mouse blastocysts. Fertil Steril 2005;83:238-42.

[18] Minegishi T, Karino S, Tano M, Ibuki Y, Miyamoto K. Regulation of midkine messenger ribonucleic acid levels in cultured rat granulosa cells. Biochem Biophys Res Commun 1996;229:799_ 805.

[19] Hattori M, Takesue K, Nishida N, Kato Y, Fujihara N. Inhibitory effect of retinoic acid on the development of immature porcine granulosa cells to mature cells. J Mol Endocrinol 2000;25:53-61.

[20] Thellin O, Zorzi W, Lakaye B, De Borman B, Coumans B, Hennen G, et al. Housekeeping genes as internal standards: use and limits. J Biotechnol 1999;75:291-5.

[21] Suzuki T, Higgins PJ, Crawford DR. Control selection for RNA quantification. Biotechniques 2000;29:332-7.

[22] Robert C, McGraw S, Massicotte L, Pravetoni M, Gandolfi F, Sirard MA. Quantification of housekeeping transcript levels during the development of bovine preimplantation embryos. Biol Reprod 2002;67:1465-72.

[23] Goossens K, Van Poucke M, Van Soom A, Vandesompele J, Van Zeveren A, Peelman LJ. Selection of reference genes for quantitative real-time PCR in bovine preimplantation embryos. BMC Dev Biol 2005;5:27.
[24] Cosma MP. Ordered recruitment: gene-specific mechanism of transcription activation. Mol Cell 2002;10:227-36.

[25] Raisner RM, Madhani HD. Patterning chromatin: form and function for H2A.Z variant nucleosomes. Curr Opin Genet Dev 2006;16:119-24.

[26] Leach TJ, Mazzeo M, Chotkowski HL, Madigan JP, Wotring MG, Glaser RL. Histone H2A.Z is widely but nonrandomly distributed in chromosomes of Drosophila melanogaster. J Biol Chem 2000;275:23267-72

[27] Jackson JD, Falciano VT, Gorovsky MA. A likely histone H2A.F/Z variant in Saccharomyces cerevisiae. Trends Biochem Sci 1996;21:466-7.

[28] Marzluff WF, Duronio RJ. Histone mRNA expression: multiple levels of cell cycle regulation and important developmental consequences. Curr Opin Cell Biol 2002;14:692-9.

[29] Wu SR, Bonner WM. Separation of basal histone synthesis from Sphase histone synthesis in dividing cells. Cell 1981;27:321-30.

[30] Dhillon N, Oki M, Szyjka SJ, Aparicio OM, Kamakaka RT. H2A.Z functions to regulate progression through the cell cycle. Mol Cell Biol 2006;26:489-501.

[31] Giono LE, Manfredi JJ. The p53 tumor suppressor participates in multiple cell cycle checkpoints. J Cell Physiol 2006;209:13-20.

[32] Wang S, El-Deiry WS. p73 or p53 directly regulates human p53 transcription to maintain cell cycle checkpoints. Cancer Res 2006;66:6982-9.

[33] Nishida H, Suzuki T, Ookawa H, Tomaru Y, Hayashizaki Y. Comparative analysis of expression of histone $\mathrm{H} 2 \mathrm{a}$ genes in mouse. BMC Genomics 2005;6:108.

[34] Li A, Chandrakanthan V, Chami O, O'Neill C. Culture of zygotes increases 553 expression in $\mathrm{B} 6$ mouse embryos, which reduces embryo viability. Biol Reprod 2007;76:362-7.

[35] Migliaccio E, Giorgio M, Mele S, Pelicci G, Reboldi P, Pandolfi PP, et al. The p66shc adaptor protein controls oxidative stress response and life span in mammals. Nature 1999;402:309-13.

[36] Favetta LA, Robert C, King WA, Betts DH. Expression profiles of p53 and p66shc during oxidative stress-induced senescence in fetal bovine fibroblasts. Exp Cell Res 2004;299:36-48.

[37] Favetta LA, Robert C, John StEJ, Betts DH, King WA. p66shc, but not $\mathrm{p} 53$, is involved in early arrest of in vitro produced bovine embryos. Mol Hum Reprod 2004;10:383-92.

[38] Trinei M, Berniakovich I, Pelicci PG, Giorgio M. Mitochondrial DNA copy number is regulated by cellular proliferation: a role for Ras and p66(Shc). Biochim Biophys Acta 2006;1757:624-30.

[39] Orsini F, Moroni M, Contursi C, Yano M, Pelicci P, Giorgio M, et al. Regulatory effects of the mitochondrial energetic status on mitochondrial p66Shc. Biol Chem 2006;387:1405-10.

[40] Trinei M, Giorgio M, Cicalese A, Barozzi S, Ventura A, Migliaccio E, et al. A p53-p66Shc signalling pathway controls intracellular redox status, levels of oxidation-damaged DNA and oxidative stress-induced apoptosis. Oncogene 2002;21:3872-8.

[41] Tiberi L, Faisal A, Rossi M, Di Tella L, Franceschi C, Salvioli S. p66(Shc) gene has a pro-apoptotic role in human cell lines and it is activated by a p53-independent pathway. Biochem Biophys Res Commun 2006;342:503-8.

[42] Hayashi K, Yokozaki H, Naka K, Yasui K, Lotan R, Tahara E. Effect of 9-cis retinoic acid on oral squamous cell carcinoma cell lines. Cancer Lett 2000;151:199-208.

[43] Rendi MH, Suh N, Lamph WW, Krajewski S, Reed JC, Heyman RA, et al. The selective estrogen receptor modulator arzoxifene and the rexinoid LG100268 cooperate to promote transforming growth factor beta-dependent apoptosis in breast cancer. Cancer Res 2004;64:3566-71. 
[44] Pinaire JA, Reifel-Miller AR. Therapeutic potential of retinoid x receptor modulators for the treatment of the metabolic syndrome. PPAR Res 2007;2007:94156.

[45] Wente W, Brenner MB, Zitzer H, Gromada J, Efanov AM. Activation of liver $\mathrm{X}$ receptors and retinoid $\mathrm{X}$ receptors induces growth arrest and apoptosis in insulin secreting cells. Endocrinology, in press.
[46] Altucci L, Gronemeyer H. The promise of retinoids to fight against cancer. Nat Rev Cancer 2001;1:181-93.

[47] Lonergan P, Rizos D, Gutierrez-Adan A, Moreira PM, Pintado B, de la Fuente J, et al. Temporal divergence in the pattern of messenger RNA expression in bovine embryos cultured from the zygote to blastocyst stage in vitro or in vivo. Biol Reprod 2003;69:1424-31. 